\title{
Implications of the variable availability of seasonal foods on the home ranges of black bears, Ursus americanus, in the Sierra Nevada of California
}

Rachel Mazur ${ }^{1,2^{*}}$, A P Klimley ${ }^{3}$ and Karen Folger ${ }^{4}$

\begin{abstract}
Background: Sugar pine (Pinus lambertiana) seeds and oak (Quercus spp.) acorns are both important fall food sources for a variety of wildlife in the Sierra Nevada, but both have variable mast production and are in decline. Sugar pines are in decline due to white pine blister rust (Cronartium ribicola) infection and oaks are in decline due to fire exclusion and mule deer (Odocoileus hemionus) predation. To examine how a change in availability of seed and acorn crops from these trees could have a cascading effect on associated wildlife, we studied their relationship to black bear (Ursus americanus) fall ranges in Sequoia National Park, California. The distribution of seed-bearing sugar pines overlaps with the bears' summer range, whereas acorn-bearing oaks occur at lower elevations. We used GPS collars and field observations to collect location data on ten wild, adult, female bears during the summer and fall of both 2005 and 2006, and then compared these data on habitat use with the Park's vegetation map of available habitat.

Results: Our results indicate that the inter-annual variability in the availability of these natural foods is closely related to the seasonal ranges of black bears. In the fall of 2005, when blue and black oak acorns were scarce but other acorns were abundant, bears remained within their summer ranges to feed on sugar pine seeds. In the fall of 2006, when blue oak acorns were abundant, bears shifted out of their summer ranges to feed on acorns and forego sugar pine seeds, even though the seeds were more abundant than in 2005. Incidents between humans and black bears were highest in 2006 while bears were moving between their summer ranges and the oak belt.

Conclusion: In the fall, black bears make heavy use of both sugar pines and oaks. Although they prefer acorns to sugar pine seeds, the loss of either food source would lead to an increased dependence on the other. When both are unavailable due to continued decline or simultaneously low mast crops, an increase in human-bear incidents is likely.
\end{abstract}

Keywords: Acorn production, Black bear, Blister rust, Home range, Preference, Sudden oak death, Sugar pine, Ursus americanus

\footnotetext{
* Correspondence: rachelmazur@rocketmail.com

'Division of Resource Management and Science, Sequoia and Kings Canyon

National Parks, Three Rivers, California 95616, USA

${ }^{2}$ Current address: Natural Resources Staff, Humboldt-Toiyabe National Forest,

1200 Franklin Way, Sparks, Nevada 89431, USA

Full list of author information is available at the end of the article
} 


\section{Background}

In California's Sierra Nevada, white pine blister rust (Cronartium ribicola) threatens the continued existence of sugar pines (Pinus lambertiana). This fungal pathogen appeared in the Southern Sierra in the 1960s, infecting many of the region's sugar pines, which are now in decline $[1,2]$. Oaks are declining due to fire exclusion and mule deer (Odocoileus hemionus) predation [3,4]. The pathogen that causes sudden oak death (Phytophthora ramorum) has not yet arrived in the Sierra, but if it does, it will also threaten the region's black oaks (Quercus kelloggii) [5]. A loss of sugar pines will likely have a cascading effect on the associated wildlife, especially if it coincides with a reduction in oaks, but with little existing research on these associations, the impacts are difficult to predict [6]. To begin addressing this gap in information, we studied the importance of the trees as food sources for black bears (Ursus americanus). Specifically, we studied how the distribution of the trees and their inter-annual variability in mast (that is, seed and acorn) production was related to bears' foraging preferences and inter-annual variation in fall home ranges in Sequoia National Park (hereafter Sequoia). We then considered how variable ranges and mast availability could affect the potential for bears to interact with humans.

One commonly given definition of home range is the 'area traversed by the individual in its normal activities of food gathering, mating, and caring for young' [7]. The area that is most frequently used within the home range is then termed the 'core area' [8]. For some wildlife species, the core area represents the den and its environs. For other species, it could be the area around a frequently used travel corridor. With bears, the bulk of movements are influenced by the abundance and spatial distribution of food, so the core area represents the bear's preferred foraging area $[9,10]$. This is especially true in the fall when bears must dramatically increase their body weight to prepare for winter [11].

Animals prefer foods that provide the greatest energetic or nutritional return for the smallest effort [12-14]. For black bears, three ecological scenarios are consistent with this hypothesis. First, there is geographical overlap of consistently available (that is, year to year) highcalorie foods across seasons, and bears establish home ranges that remain stable across seasons $[15,16]$. Second, there is geographical separation of consistently available high-calorie foods in different seasons, so bears shift their home ranges each season to exploit the higher calorie foods [9]. Third, high-calorie foods geographically overlap across seasons, but are not available in all years. In years when the high-calorie foods are available, bears maintain stable home ranges. In years when the highcalorie foods fail or higher calorie foods are available nearby, bears leave their established range to exploit those alternate high-calorie foods [17].

In the Sierra Nevada, black bear spring and summer seasonal foods mostly occur at middle elevations; in spring, they feed largely on grasses; and in summer, they feed on insects, berries, and mule deer (Odocoileus hemionus) fawns. The spatial distribution of fall foods, including conifer seeds and acorns [18], is more variable. Seedbearing sugar pines are patchily distributed at middle elevations and overlap with summer foods, whereas acorn-bearing oaks have a clumped distribution and occur at lower elevations. Both come from masting trees and are unpredictable in their annual availability. A mature blue oak (Quercus douglasii) may produce over 100,000 acorns in a mast year, and few or no acorns in a poor year [19]. During all seasons, bears may forage on human food and garbage when it is available [20].

Based on the three potential scenarios and the distribution of sugar pines and oaks, we expected bears in Sequoia to forage in the same area every summer, but to exploit different areas during fall, depending on the availability and relative caloric value of nearby versus distant foods. That would mean that during years that seeds are abundant, they would remain at high elevations to feed on seeds and forego acorns, whereas during years that seeds are scarce or acorns plentiful, they would shift their range to lower elevations to feed on acorns, and forego feeding on seeds [17]. Since both conifer seeds and acorns are high in calories, we also expected the period when these natural foods are most abundant to be related to a reduction in the bears' use of human food [21], and therefore, unwanted human-bear incidents [22,23]. The reduction in human-bear incidents is a common goal of wildlife managers [24-26].

\section{Results}

\section{Bear data}

We collected data on ten bears in 2005 and ten bears in 2006, including five of the same bears in both 2005 and 2006. Because we installed collars throughout the month of July, we limited our analyses to bears tracked between 1 August and 30 October [27]. There was an average fix success rate among bears of $74 \%$, with a range of 66 to $88 \%$. The minimum number of fixes acquired by any collar on a single day was six, and the maximum was twenty-four. All collars acquired a minimum of nine fixes on at least $95 \%$ of the days they were deployed. By time of day, the highest average fix success rate was $86 \%$ at 1400 hours. The lowest rate was $57 \%$ at 0500 hours.

\section{Acorn and sugar pine seed production}

There were significant differences in acorn output among oak species within years $\left(F_{2}, 432=4.75, P=0.009\right)$ and among years within species $\left(F_{3,432}=34.77, P<0.001\right)$ 
based on a linear mixed effect model. In 2005, canyon oak had high acorn production based on standardized counts (>20/second), interior live oak had moderate acorn production ( $>10 /$ second) and black oak and blue oak had low acorn production $(<5 /$ second). In 2006 , canyon oak and blue oak had high acorn production $(>20 /$ second) and interior live oak and black oak had low acorn production $(<5 /$ second). Oregon oak was not included in the acorn survey, but anecdotally exhibited high acorn production in 2006 but not in 2005 (R Mazur, personal observation). Sugar pine seed production in 2005 was $116 \%$ above an 8year average, and in 2006 was 308\% above average (Van Mantgem, United States Geological Survey (USGS), personal communication).

\section{Home range estimation}

Using 99\% kernels to estimate each bear's home range for the entire study period (August to October), home ranges were significantly larger in 2006 (mean $=25.60 \mathrm{~km}^{2}, \mathrm{SD}=$ $\left.12.6 \mathrm{~km}^{2}\right)$ than in $2005\left(\right.$ mean $\left.=9.24 \mathrm{~km}^{2}, \mathrm{SD}=3.34 \mathrm{~km}^{2}\right)$ $\left(F_{1,4}=19.59, P=0.012\right)$. When home ranges were compared by year and month simultaneously, sizes differed both by month $\left(F_{2,39}=11.6, P<0.001\right)$ and by year $\left(F_{1,39}=\right.$ 8.46, $P=0.006$ ), with no significant interaction effect. The month effect was due to differences in 2006, when home range sizes were stable between August and September $(t=1.69, \mathrm{df}=39, P=0.223)$, but then increased significantly between September and October $(t=4.76, \mathrm{df}=39, P<$ 0.001 ) when bears moved out of their summer ranges to lower elevations for acorns. In 2005, home range sizes were stable across all months, when bears remained in their summer ranges to feed on sugar pine seeds.

Using 50\% kernels to estimate each bear's core area for the entire study period, we found the size of core areas was stable in both years between August and September $(t=1.03, \mathrm{df}=39, P=0.561)$, and then decreased significantly in October $(t=5.42, \mathrm{df}=39, P<0.001)$. In October, the bears' foraging efforts were targeted on concentrated sources of high calorie food: sugar pine seeds in 2005 and acorns in 2006.

In 2005, the average overlap between August and October home ranges was $74 \%$ whereas in 2006 , the average overlap between August and October home ranges was $32 \%$. Limiting the comparison to core areas, all bears' October core area overlapped with their August core area in 2005, whereas in 2006 none of the bears' October core areas overlapped with their August core areas. In 2006, the mean distance between centers of activity from August to October $($ mean $=0.433 \mathrm{~km}$, sd $=$ $0.311)$ was significantly greater $\left(F_{2,38}=6.06, P=0.005\right)$ than in 2005 (mean $=0.099 \mathrm{~km}, \mathrm{SD}=0.094$ ). These data indicate that in 2006, the bears shifted out of their range from summer to fall, rather than simply expanding it, to exploit acorns while entirely foregoing the use of sugar pine seeds (Figure 1).

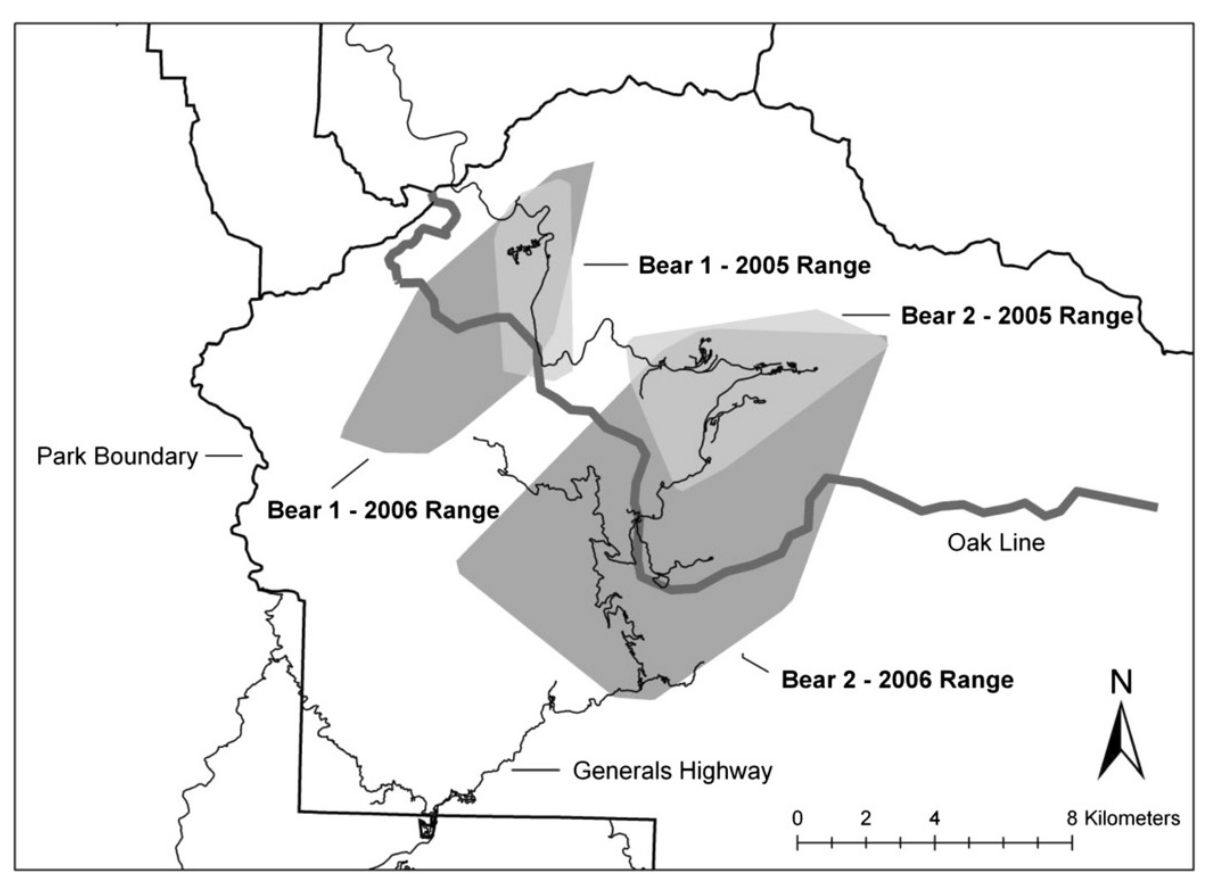

Figure 1 Minimum convex polygons (100\%) of the home ranges for two bears that were collared in both 2005 and 2006 in Sequoia National Park, California. This shift from small home ranges above the oak belt in 2005 to larger home ranges encompassing the oak belt in 2006 was characteristic of all bears in this study. The dark line indicates the northern boundary for oaks. 
To determine whether data collected in August were representative of the summer (that is, July and August), we calculated for each bear that we had a minimum of 20 days of July data, the percent of each bear's July range that overlapped with its August range. We used 100\% minimum convex polygons (MCPs) for simplicity. In 2005, we had July records for seven bears, which had an average overlap with August of $82 \%$. In 2006, we had July data for five bears, which had an average overlap with August of 91\%. Therefore, we concluded that August was representative of summer for each year.

\section{Habitat use}

Bears did not establish home ranges randomly among habitat types. Grouping August through October in 2005, they occupied habitats in the following ranked order of preference: conifers > other > oaks (compositional analysis, Wilks' lambda, $P<0.001)$. The result held when we compared occupied habitats by month. That year, sugar pine was occupied nearly three times more than would be expected based on availability.

Grouping August through October in 2006, bears didn't show any preference among habitats $(P=0.348)$, but this result changed dramatically when we separated the location data by month. In August, bears occupied conifers significantly more than oaks $(P=0.031)$. They occupied habitats in proportion to their availability in September $(P=0.776)$, and in October, bears occupied oaks significantly more than conifers $(P=0.007)$.

Our hundreds of hours of field observations showed that actual foraging behavior was consistent with our assumptions based on habitat use. In the fall, bears were focused on sugar pine seeds in 2005 and on acorns in 2006. We recorded no observations of these collared bears foraging on human food.

To determine whether bears preferred certain species of acorns, we ran a compositional analysis for October 2006 comparing available oak habitat (broken down by Quercus species) with occupied oak habitat. Canyon oak, blue oak, and black oak were occupied disproportionally more than live oak or Oregon oak $(P<0.001)$.

To determine whether bears were exhibiting a preference for sugar pines over other conifer species, we compared available versus occupied habitat containing conifers in 2005, the year the bears preferred conifers. Throughout the season, sugar pine was strongly preferred, being occupied $176 \%$ more than would be expected based on availability.

Graphs comparing the weekly average size of core use areas with the percent of the core area that is composed of each year's preferred food type indicates that these variables are related (Figures 2a, 2b). The core areas are smallest when bears are feeding on acorns, which are more clumped in their distribution than sugar pine. Using Spearman-rank correlation coefficients to test these relationships, the

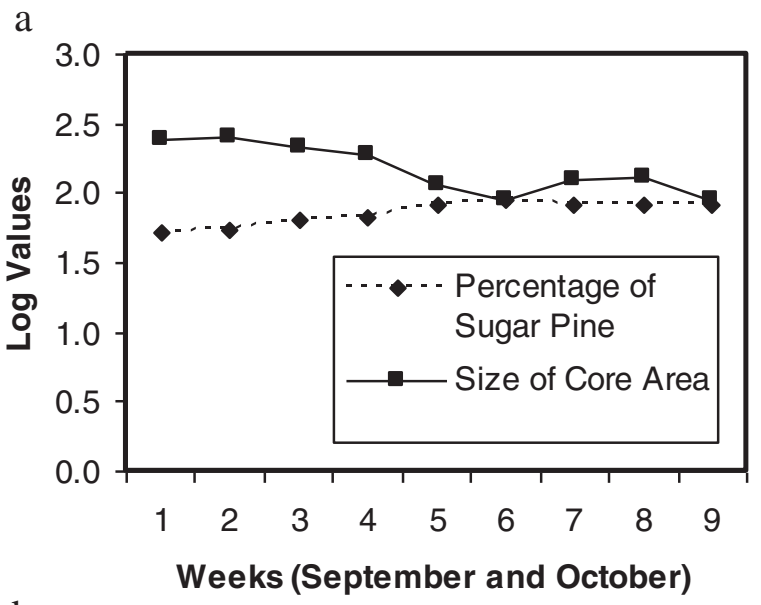

b

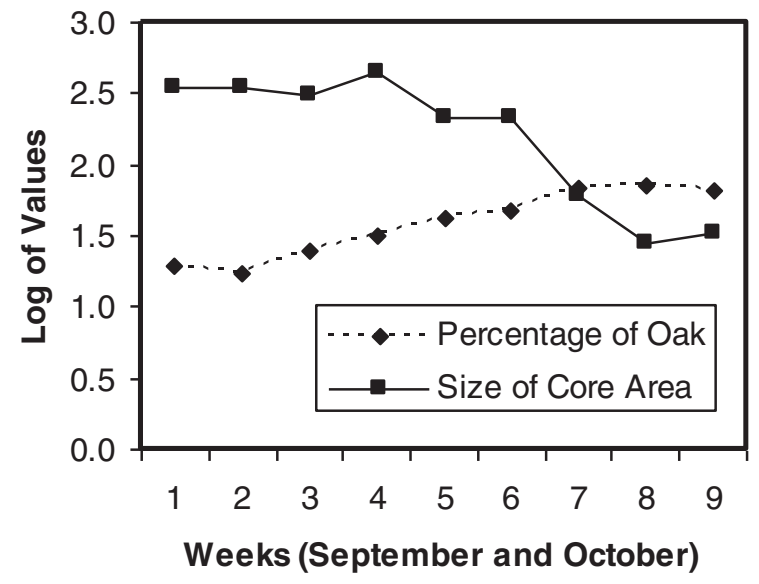

Figure 2 Relationships between percentages of preferred food types in core use areas and size of core use areas of female adult black bears in Sequoia National Park. (a) Relationship between log values of percentage of sugar pine in core use areas and size of core use areas of female adult black bears in 2005. (b) Relationship between log values of percentage of oak in core use areas and size of core use areas of female adult black bears in 2006.

percentage of sugar pine is significantly correlated with core size (rho $=0.889, \mathrm{n}=13, P<0.001$ ). Percentage of acorns is not significantly related to core area ( $r h o=0.445, \mathrm{n}=13, P=$ 0.128 ), probably because large core areas result from bears moving out of their summer range.

\section{Relation to human-bear incidents}

We hypothesized that the availability of high-calorie natural foods reduces the bears' motivation to seek human food and therefore reduces human-bear incidents. In 2005, when natural foods were abundant in overlapping areas throughout summer and fall, bears remained in their summer ranges to gorge on abundant sugar pine seeds. By the beginning of September, human-bear incidents in Sequoia dropped to zero. In 2006, summer and fall foods were abundant, but did not occur in overlapping areas. 
That September, bears left their summer ranges to find high-calorie foods. During this transition, there was an average of 2.8 days each week with human-bear incidents within Sequoia, compared with zero incidents during the same period of 2005. Then, when bears were settled into their fall ranges and feeding on the fall acorn crop, incidents again dropped to zero.

\section{Discussion and conclusion}

In Sequoia, summer seasonal foods for bears occur in overlapping areas, while fall foods are more widely distributed across the landscape. Sugar pine nuts are patchily distributed and overlap with summer foods, while acorns have a clumped distribution and occur at lower elevations. Both are highly nutritious, with sugar pine nuts being smaller than acorns, but having a higher fat content. As masting species, both are unpredictable in their annual availability. It follows that bears should only expend extra time and energy to travel for acorns when the acorn crop is particularly good or the sugar pine seed crop is inadequate.

In the fall of 2005, when blue and black oak acorns were scarce but other acorns were abundant, bears remained in small areas overlapping with their summer ranges to feed on an average-sized crop of sugar pine seeds and forego feeding on acorns. In the fall of 2006, when blue oak acorns were abundant, bears shifted out of their summer ranges to feed on acorns and forego feeding on sugar pine seeds, even though the seeds were almost three times more abundant than in 2005. During weeks in 2005 when bears fed on sugar pine seeds, the average size of their core area was small, but was not as small as that of bears feeding on acorns in 2006. The bears therefore did not shift their ranges when the sugar pine seed crop was inadequate, but when the blue oak acorns were plentiful.

When bears did shift their ranges to feed on acorns, they preferred those from blue oak over canyon oak and interior live oak. Blue oaks have much larger, more accessible acorns than the other two types, allowing for greater foraging efficiency. In this study, there was no year with a high black oak acorn crop. Bears are known to feed on black oak acorns, which have higher fat content than other acorns, a reason Native Americans prized them [28]. Since black oaks also grow at higher elevations than the other oak species and are thus closer to the bears' summer range, it is likely that in years black oak acorns are abundant, bears would prefer them over blue oak acorns.

The importance of high-calorie foods to bears cannot be understated. In the fall, bears must consume thousands of calories a day to survive the winter [29]. Fall body mass is correlated with female reproduction, fetal growth, and cub survival [30,31].
When bears do shift their ranges, they often come into greater contact with humans and roads. Some bears are hit by cars [32] and others begin foraging on highcalorie human foods, resulting in human-bear conflict [33]. It follows that during these shifts, or in years when natural food is insufficient to meet bears' needs, humanbear incidents increase. This was the case in Sequoia during this study. Incidents were highest in 2006 during the period when bears were moving from their summer ranges to the oak belt to forage on acorns. Confounding factors include the location of core areas in relation to roads or human structures and the potential for park visitors to approach bears in different areas.

It is possible that black bears in the Sierra will lose these high-calorie food sources. Blister rust has already reduced sugar pines to a fraction of their original range [2]. Since these trees occur on a steep elevation gradient, future seedling recruitment will likely be vulnerable to climate change [34]. Oaks are vulnerable to the fungal pathogen responsible for sudden oak death, and outside of protected areas, thousands of hectares of oaks are also lost each year to land conversion and wood cutting $[35,36]$. In the short-term, this loss of natural food will likely lead to an increase in human-bear conflict. Park rangers could proactively reduce the potential for conflict by increasing patrols of human-use areas in the transition zones when bears are shifting resources. Over the longer-term, a loss of natural food could result in a reduction in the Sierra's carrying capacity for bears.

\section{Methods}

\section{Study area}

This study took place in Sequoia National Park, which is comprised of 164,475 hectares on the western slope of the Sierra Nevada in California. Sequoia ranges in elevation from 418 meters in the low western foothills to 4,417 meters on the crest of the Sierra. At the lower elevations, topography is rugged and steep, rising to a gently rolling plateau at middle elevations, and then rising again more gradually into the remote alpine wilderness. The plateau contains numerous montane hydric meadows of grasses, forbs, and sedges. The region's Mediterranean climate is characterized by wet, snowy winters and long, dry summers [37]. Mean annual precipitation is highly variable, but ranges from $66 \mathrm{~cm}$ in the foothills to $125 \mathrm{~cm}$ at 2,000 $\mathrm{m}$, where more than half falls as snow.

Because of the steep topography, there are dramatic differences over short distances in vegetation, which may be divided into five principle plant communities. From low to high elevations, they include chaparral, oak woodland, upland hardwood forest, mixed conifer forest, and alpine plant communities, the latter of which has little importance to bears. The four common species of oak that are found within the oak woodland and upland 
hardwood forest are interior live oak (Quercus wislizeni), blue oak, canyon live oak (Quercus chrysolepis), and black oak. Sugar pine is found in the mixed conifer forest, along with giant sequoia (Sequoiadendron giganteam), white fir (Abies concolor), and jeffrey pine (Pinus jeffreyi).

\section{Bear data}

We used dart guns (Daninject, Wildlife Pharmaceuticals, Fort Collins, CO, USA) and metal culvert traps to capture bears in Sequoia National Park during May, June, and July in 2005 and 2006. We classified bears that were not known to enter developed areas to obtain human food as wild, and bears older than four years as adults [38]. We targeted wild adult female bears found within 0.8 kilometers of a development or road within the mixed conifer forest. Bears were immobilized using Telazol $(4.4 \mathrm{mg} / \mathrm{kg}$, Fort Dodge Laboratories, Fort Dodge, IA, USA), marked with colored and uniquely numbered ear tags (Allflex International, Dallas, TX, USA), and fitted with a global positioning system (GPS) radio collar (Telonics Inc., Mesa, Arizona, USA). Each collar was programmed to record the bear's location every hour, and to store the resulting data. A breakaway mechanism on each collar was programmed to deploy on 31 October of the same year, so the collar could be retrieved and data downloaded. Standard measurements were also taken. All handling operations were approved by the U. C. Davis Animal Care and Use Committee (IACUC \#11520).

We screened all data for sources of error and bias [39]. Data from the first two days after a bear's capture were deleted to eliminate the effects of immobilization on its movements, as were data from the day the collar dropped off in case any mechanism released early. We found no obvious outliers caused by limited satellites or problems with positional dilution of precision based on the geometry of the satellites. In testing for statistical independence, we found that hourly fixes were temporally auto-correlated; however, this had negligible effect on area estimation $[40,41]$ and reduced the accuracy of the area estimations, so we kept all hourly points. The resultant geographical coordinates, each representing an hourly position of the bear, were then imported into ArcGIS (version 9.1) for analysis.

\section{Acorn and sugar pine seed production}

The weakness in depending upon habitat maps to measure proportional food availability is that vegetation types represent potential, but not actual, food availability. If food production varies with easily measured variables such as annual precipitation and temperature, food availability at particular times may be inferred. With masting species such as oaks and pines, which produce annually variable acorn crops, such inferences are not possible. Therefore, we systematically sampled acorns by marking
148 individual oaks along the Generals Highway in Sequoia National Park with both a handheld GPS unit (Etrex Vista, Garmen Ltd., Olathe, KS, USA) and a written description with mile-markers and photographs. The Generals Highway provides a useful cross-section of the four common species of oak, allowing us to catalog the location of each tree without using permanent outdoor markers. The sample included 44 Q. douglasii, 29 Q. kelloggii, 40 Q. wislizeni, and 35 Q. chrysolepis. We evaluated acorn production between mid-September and early October of 2005 and 2006 using the visual survey technique developed by Koenig et al. [42]. Two observers, stationed at opposite sides of a tree, focused on different parts of the crown and counted all acorns seen in 15 seconds; the sum yielding an index of total acorns counted in 30 seconds. Data were again analyzed with linear mixed effect models.

Relative abundance of sugar pine seeds was obtained from the USGS Western Ecological Research Center, where data on conifer seed production in Sequoia National Park are collected as part of an ongoing forest demography study. See van Mantgem et al. [34] for methodology.

\section{Home range estimation}

Using the Home Range Tools extension for ArcGIS [43], we calculated home ranges using 99\% kernels (excluding minimally used areas only), and core areas using 50\% kernels. Kernels have several advantages over MCPs. Kernels are not dependent on outlying points to define their boundaries, they give insight into core activity areas, and they can exclude internal areas that were unused by the animal [44]. Since bears tend to clump their activities, rather than spread them evenly across the landscape [45], kernels are an appropriate means to represent their use patterns [8].

While kernels are widely preferred for estimating home ranges $[46,47]$, there is less agreement on the appropriate smoothing factor (h) [48], which determines the kernel's width at each point in space and affects the estimate of home range size [49-51]. We applied three commonly used smoothing factors; least squares cross validation (lscv), reference bandwidth (h-ref) and likelihood crossvalidation (CVh) (Figure 3). Lscv created too much detail, and could not estimate home range because it produced disjunct contours with multiple local minima. Both CVh and h-ref had good surface fit, but oversmoothed the data, thus overestimating the home range distributions [52]. To bring the outer edge of the home range estimate closer to the outer point locations while retaining the surface fit, we used a scaled h-ref of 0.3. We used fixed versus adaptive kernels so areas of both low and high densities would receive an equal amount of smoothing [53,54].

We used these kernels to test for differences in the sizes of home ranges and core areas on three time scales: whole season (that is, August to October), month, and 


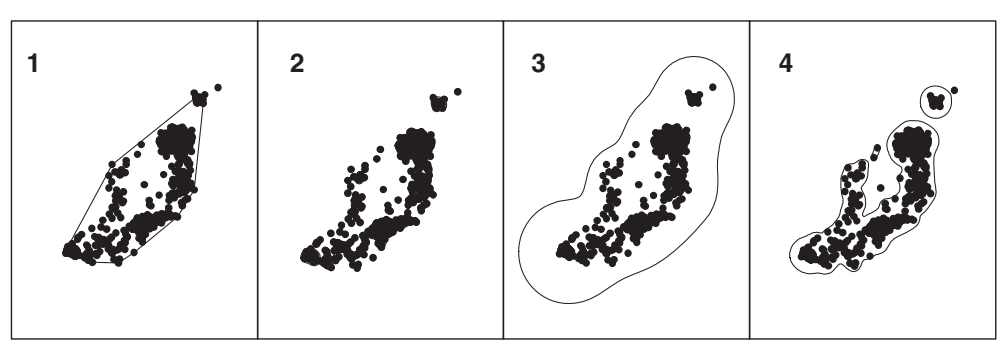

Figure 3 Hourly location data for one bear transformed into home range diagrams. Data were transformed using (1) minimum convex polygon; (2) least squares cross-validation; (3) reference bandwidth and likelihood cross-validation, and (4) scaled reference bandwidth (0.3). These data are from 2006 in Sequoia National Park, CA, USA.

week. We then compared the geographic locations of home ranges and core areas in August with October of each year to determine whether they were expanding or shifting over time. The mean center function in ArcGIS was used to locate the activity centers and the point distance function to calculate the distance between centers. To evaluate differences in the distributions of activity, we calculated the percent overlap between the home ranges and the core areas during successive time periods.

Individual bears were the units of analysis [55,56]. We used linear mixed effect models to account for using some of the same bears in both years. The fit of each model was assessed using a graphical analysis of residuals and the Shapiro-Wilk test for normality. Where necessary, data were log transformed. Post hoc tests of pairwise differences were performed using the TukeyKramer adjustment for multiple comparisons. Differences were considered statistically significant at $\mathrm{P}<0.05$. Tests were performed using SAS (version 9.1).

\section{Habitat Use}

We used geographic information systems (GIS) to compare the habitat bears actually used with available habitat. We derived our habitat layer from the Park's recently completed vegetation map, which has an overall accuracy of $86 \%$ at the alliance level based on 2,409 field assessments [57]. We created a new vegetation layer by combining the alliances into three broad groups: conifers, oaks, and other. We also created a more detailed version of this layer; sugar pines, other conifers, blue oak, black oak, Oregon oak, canyon oak, interior live oak, and other.

We defined boundaries for maps of available habitat by merging the location data from all bears across all years, using this merged file to create a $99 \%$ kernel, and then adding a 5-km buffer (based on the maximum distance an adult female traveled in an hour during this study). We overlaid each bear's hourly location data on the habitat map to determine the actual proportional habitat use for that bear. These data were not independent, but rather purposefully systematic, thus allowing us to approximate the true proportional habitat use [55]. Due to the low error, and the ability of GPS to estimate point locations more precisely than conventional telemetry [58] we did not need to buffer these points. We replaced any values of $0 \%$, representing available but unutilized habitat, with $0.01 \%$, an order of magnitude less than the smallest observed value [55] and used RSW software [59] for compositional analyses.

To cross-check our results, we compared available with used habitat for the five bears collared in both 2005 and 2006. For each bear, we defined the boundary of their available habitat by merging the two years of location data, using the merged data to create a $99 \%$ kernel, and adding a 5-km buffer. This was done separately for each bear.

We verified our assumptions of foraging targets based on habitat use with daily field observations of every collared bear. In most cases, we, or our field crews, located and observed bears multiple times a day. Bears in this study had white GPS collars while other park bears had black very high frequency (VHF) collars, so we also trained rangers to collect observation data. They were nearly continuously present in developed areas between 0700 and 0200 hours and could verify that these whitecollared bears were not foraging on human food.

We used Spearman-rank correlation coefficients to test if there was a relationship over time between the percentage of high-quality food types with core areas and the size of core areas used by bears. We also assessed this relationship graphically, plotting the weekly variation in the mean size of core areas for each year. We then plotted the weekly variation in the percent of the core area composed of the preferred food type for each year and compared the results. These plots are limited to September and October in order to focus on the bears' movements toward the fall mast.

\section{Relation to human-bear incidents}

We used Sequoia's definition of a human-bear incident, that being any encounter between a human and a bear that results in the bear obtaining or damaging human 
food or property, the bear acting aggressively toward a human, or an injury to either the bear or the human. To compare incidents to habitat quality, we used the weekly average size of core areas as an index of the bears' use of high-quality foods (August to October) and compared it with the number of days each week that human-bear incidents were recorded in the Park's Bear Incident Management System [60].

\section{Abbreviations}

CVh: Likelihood cross-validation; GIS: Geographic information systems; GPS: Global positioning system; h-ref: Reference bandwidth; Iscv: least squares cross validation; MCP: Minimum convex polygon; USGS: United States Geological Survey; VHF: Very high frequency.

\section{Competing interests}

The authors declare that they have no competing interests.

\section{Authors' contributions}

RLM designed the study, acquired funding, collected and analyzed the data and wrote the manuscript. APK assisted with study design, data analysis, and manuscript editing. KF assisted with the analysis and interpretation of the data. All authors read and approved the final manuscript.

\section{Acknowledgements}

This study was made possible by the excellent work of T Allai, J Clarke, W Jaynes, A Kleist, R Leahy, L Long, T McKenna, J Petriello, T Seher, J Sturdevant, J Taylor, M Wagman, J. West, L West, and R West. D Graber, D Kelt, W Koenig, A Sih, H Werner, and R Woodroffe generously provided advice and suggestions. We are grateful to P Lineback for his help with GIS and J Braun for his statistical advice.

\section{Author details}

'Division of Resource Management and Science, Sequoia and Kings Canyon National Parks, Three Rivers, California 95616, USA. ${ }^{2}$ Current address: Natural Resources Staff, Humboldt-Toiyabe National Forest, 1200 Franklin Way, Sparks, Nevada 89431, USA. ${ }^{3}$ Department of Wild life, Fish, and Conservation Biology, University of California, 1334 Academic Surge, Davis, California 95616, USA. ${ }^{4}$ Division of Resource Management and Science, Sequoia and Kings Canyon National Parks, 47050 Generals Highway, Three Rivers, California 95616, USA.

Received: 5 June 2013 Accepted: 16 August 2013

Published: 25 October 2013

\section{References}

1. Duriscoe DM, Duriscoe CS: Survey and monitoring of white pine blister rust in Sequoia and Kings Canyon National Parks. Sequoia and Kings Canyon National Park, Three Rivers, California: National Park Service; 2002

2. van-Mantgem PJ, Stephenson NL, Keifer MB, Keeley JE: Effects of an introduced pathogen and fire exclusion on the demography of sugar pine. Ecol Appl 2004, 14:1590-1602.

3. Nixon KC: Quercus. In Flora of North America North of Mexico. New York and Oxford: Flora of North America Editorial Committee; 1997.

4. Ripple WJ, Beschta RL: Trophic cascades involving cougar, mule deer, and black oaks in Yosemite National Park. Biol Conserv 2008, 141:1249-1256.

5. MCPherson BA, Mori SR, Wood DL, Storer AJ, Svihra P, Kelly NM, Standiford RB: Sudden oak death in California: disease progression in oaks and tanoaks. For Ecol Manage 2005, 213:71-89.

6. Monahan WB, Koenig WD: Estimating the potential effects of sudden oak death on oak-dependent birds. Biol Conserv 2006, 127:146-157.

7. Burt WH: Territoriality and home range concepts as applied to mammals. J Mammal 1943, 24:346-352.

8. Samuel MD, Pierce DJ, Garton EO: Identifying areas of concentrated use within the home range. J Anim Ecol 1985, 54:711-719.

9. Garshelis DL, Pelton MR: Movements of black bears in the Great Smoky Mountains National Park. J Wildl Manag 1981, 45:912-925.
10. Schooley RL, McLaughlin CR, Krohn WB, Matula GJ Jr: Spatiotemporal patterns of habitat use by female black bears during fall. Int Conf Bear Res Manag 1994, 8:143-154.

11. Garshelis DL, Pelton MR: Activity of black bears in the Great Smoky Mountains National Park. J Mammal 1980, 61:8-19.

12. MacArthur RH, Pianka ER: An optimal use of a patchy environment. Am Nat 1996, 100:276-282.

13. Schoener TW: Simple models of optimal feeding-territory size: a reconciliation. Am Nat 1983, 121:608-629.

14. Schoener TW: Theory of feeding strategies. Annu Rev Ecol Syst 1971, 2:369-390

15. Amstrup SC, Beecham J: Activity patterns of radio-collared black bears in Idaho. J Wildl Manag 1976, 40:340-348.

16. Klenner $\mathrm{W}$ : Seasonal movements and home range utilization patterns of the black bear, Ursus americanus, in Western Manitoba. Canadian FieldNaturalist 1987, 101:558-568.

17. Samson C, Huot J: Reproductive biology of female black bears in relation to mass in early winter. J Mammal 1998, 76:68-77.

18. Graber DM, White M: Black bear food habits in Yosemite National Park. Int Conf Bear Res Manag 1980, 5:1-10.

19. Koenig WD, Knops JMH: The mystery of masting in trees. Am Sci 2005, 93:340-347.

20. Mazur R: Does aversive conditioning reduce human-black bear conflict? J Wildl Manag 2010, 74:48-54.

21. Peirce KN, Van-Daele LJ: Use of a garbage dump by brown bears in Dillingham, Alaska. Ursus 2006, 17:165-177.

22. Peine JD: Nuisance bears in communities: strategies to reduce conflict. Hum Dimens Wild 2001, 6:223-237.

23. Walraven ME: A simulation model for management of black bear problems in Sequoia National Park. Cal-Neva Wildlife 1978, 1978:52-64.

24. Bargali AH, Akhtar N, Chauhan NPS: Feeding ecology of sloth bears in a disturbed area in central India. Ursus 2004, 15:212-217.

25. Fredriksson G: Human sun-bear conflicts in East Kalimantan, Indonesian Borneo. Ursus 2005, 16:130-137.

26. Jorgenson P, Sandoval-A S: Andean bear management needs and interactions with humans in Columbia. Ursus 2005, 16:108-116.

27. Barg JJ, Jones J, Bobertson RJ: Describing breeding territories of migratory passerines: suggestions for sampling, choice of estimator, and delineation of core areas. J Anim Ecol 2005, 74:139-149.

28. Heizer RF, Elsasser AB: The Natural World of the California Indians. Berkeley: University of California Press; 1980

29. Brown G: The Great Bear Almanac. New York: The Lyons Press; 1993.

30. Elowe KD, Dodge WE: Factors effecting black bear reproductive success and cub survival. J Wildl Manag 1989, 53:962-968.

31. Rogers LL: Effects of food supply and kinship on social behavior, movements, and population growth of black bears in northeastern Minnesota. Wildl Monogr 1987, 97:1-72.

32. Mazur $\mathrm{R}$, Seher $\mathrm{V}$ : Socially learned foraging behaviour in wild black bears, Ursus americanus. Anim Behav 2008, 75:1503-1508.

33. Mattson DJ, Blanchard BM, Knight RR: Yellowstone grizzly bear mortality, human habituation, and whitebark pine seed crops. J Wild Manag 1992, $56: 432-442$

34. van-Mantgem PJ, Stephenson NL, Keeley JE: Forest reproduction along a climatic gradient in the Sierra Nevada, California. For Ecol Manage 2006, 225:391-399.

35. Bolsinger CL: The hardwoods of California's timberlands, woodlands, and savannas. Portland: USDA Forest Service, Resource Bulletin PNW-RB-148. Pacific Northwest Research Station; 1988

36. Knapp EE, Goedde MA, Rice KJ: Pollen-limited reproduction in blue oak: implications for wind pollination in fragmented populations. Oecologia 2001, 128:48-55

37. Stephenson NL: Climate control of vegetation distribution: the role of the water-balance with examples from North America and Sequoia National Park, California, PhD thesis. Ithaca, USA: Cornell University; 1988

38. Keay JA: Black bear reproductive rates in Yosemite National Park. California Fish and Game 1995, 81:122-131.

39. D'eon RG: Effects of a stationary GPS fix-rate bias on habitat-selection analysis. J Wildl Manag 2003, 2003:858-863.

40. de-Solla SR, Bonduriansky R, Brooks RJ: Eliminating autocorrelation reduces biological relevance of home range estimates. J Anim Ecol 1999, 68:221-234 
41. McNay RS, Morgan JA, Bunnel FL: Characterizing independence in observations of movements of Columbian black-tailed deer. J Wildl Manag 1994, 58:422-429.

42. Koenig WD, Mumme RL, Carmen WJ, Stanback MT: Acorn production by oaks in central coastal California: variation within and among years. Ecology 1994, 75:99-109.

43. Rogers AR, Carr AP: HRE: the home range extension for ArCView. User's Manual. Centre for Northern Forest Ecosystem Research. Canada: Ontario Ministry of Natural Resources; 1998.

44. Hemson G, Johnson P, South A, Kenward R, Ripley R, MacDonald D: Are kernels the mustard? Data from global positioning system (GPS) collars suggest problems for kernel home-range analyses with least-squares cross-validation. J Anim Ecol 2005, 74:455-463.

45. Horner MA, Powell RA: Internal structure of home ranges of black bears and analyses of home-range overlap. J Mammal 1990, 71:402-410.

46. Kernohan BJ, Gitzen RA, Millspaugh JJ: Analysis of animal space use and movements. In Radio Tracking and Animal Populations. Edited by Millspaugh JJ, Marzluff JM. San Diego: Academic Press; 2001.

47. Powell RA: Animal home ranges and territories and home range estimators. In Research Techniques in Animal Ecology: Controversies and Consequences. Edited by Boitani L, Fuller TK. New York: Columbia Univerity; 2000.

48. Bundell GM, Maier JAK, Debevec EM: Linear home ranges: effects of smoothing, sample size, and autocorrelation on kernel estimates. Ecol Monogr 2001, 71:469-489.

49. Horne JS, Garton EO: Likelihood cross-validation versus least squares cross-validation for choosing smoothing parameter in kernel homerange analysis. J Wildl Manag 2006, 70:641-648.

50. Silverman BW: Density estimation for statistics and data analysis. London: Chapman and Hall; 1986

51. Worton BJ: Using Monte-Carlo simulation to evaluate kernel-based home range estimators. J Wildl Manag 1995, 59:794-800

52. Naef-Daenzer B: A new transmitter for small animals and enhanced methods of home-range analysis. J Wild Manag 1993, 57:680-689.

53. Seaman DE, Millspaugh JJ, Kernohan BJ, Brundige GC, Raekeke KJ, Gitzen RA: Effects of sample size on kernel home range estimates. J Wildl Manag 1999, 63:739-747.

54. Seaman DE, Powell RA: An evaluation of the accuracy of kernel density estimators for home range analysis. Ecology 1996, 77:2075-2085.

55. Aebischer NJ, Robertson PA, Kenward RE: Compositional analysis of habitat use from animal radio-tracking data. Ecology 1993, 74:1313-1325.

56. Sokal RR, Rohlf FJ: Biometry: the principles and practice of statistics in biological research. 3rd edition. New York: W. H. Freeman and Co.; 1995.

57. National Park Service: Vegetation of Sequoia and Kings Canyon National Parks. Three Rivers, California: National Park Service; 2007.

58. Girard I, Ouellet JP, Courtois R, Dussault C, Breton L: Effects of sampling effort based on GPS telemetry on home range size estimations. J Wildl Manag 2002, 66:1290-1300

59. Leban F: Resource selection analysis software. Moscow, Idaho: University of Idaho; 1999.

60. National Park Service: Bear Incident Management System for Sequoia and Kings. Canyon National Parks. Three Rivers, California: National Park Service; 2006

\section{doi:10.1186/2050-3385-1-16}

Cite this article as: Mazur et al: Implications of the variable availability of seasonal foods on the home ranges of black bears, Ursus americanus, in the Sierra Nevada of California. Animal Biotelemetry 2013 1:16.

\section{Submit your next manuscript to BioMed Central and take full advantage of:}

- Convenient online submission

- Thorough peer review

- No space constraints or color figure charges

- Immediate publication on acceptance

- Inclusion in PubMed, CAS, Scopus and Google Scholar

- Research which is freely available for redistribution

Submit your manuscript at www.biomedcentral.com/submit
Biomed Central 